\title{
At-Ta'Dîb as the Education Punishment: an Analysis of Reasons for Beating the Children in Islamic Law (A Case Study Junior High School in Indonesian)
}

\author{
Jarudin $^{1}$, Salma ${ }^{2}$, Edwar Kemal ${ }^{3}$, Wahyudi Rahmat ${ }^{4}$, and Radhya Yusri ${ }^{5}$ \\ \{jarudin@stkip-pgri-sumbar.ac.id ${ }^{1}$ \} \\ 1,3,4,5 STKIP PGRI Sumatera Barat ${ }^{2}$ Universitas Islam Negeri Imam Bonjol Padang, Indonesia
}

\begin{abstract}
Abstarct. This paper examines how Hadith of Prophet Muhammad S.A.W allow the right of parents to educate their children by beating (fadhribûhum) when they are reluctant to establish prayers. Therefore, education is often used as a justification to hit students whether parents to their children or teachers to their students. Researchers have attempted to interpret the fadhribûhum's pronunciations in many meanings such as light blows, harmless, blows / hearts and others in order to suggest if Islamic education does not tolerate beatings. Apart from the various understanding of the pronunciation of beating the child in the hadith, it is undeniable that the spell of hitting in education is indeed presented in the Qur'an and the traditions that Muslims believe as the source of the teachings. Although results of the study mentions that the Prophet Muhammad S.A.W never hit the child and his students but the appearance of the verse and the hadith is not without the purpose of goodness. The phenomenon of children's involvement in criminal acts such as theft, murder, drug abuse and even rape indicates that the hadiths that legalize beatings on the child are apparently necessary to educate ( $\left.t a^{\prime} d i b\right)$ those who deserve such an education. This paper is explored by library research thorugh collecting literature materials related to the topic of study, separating, reading, analyzing and drawing a conclusion.
\end{abstract}

Keywords: child, punishment, Islam, education, beating (dharaba)

\section{INTRODUCTION}

A child is a gift given by God S.W.T to his parents. Therefore, every parent is responsible for the fulfillment of children's rights. For example, they have a right for a proper education such as education that fills the spirit of their children through the teachings of monotheism and worship as stated on the Qur'an chapter of Luqman (31): 12-19, preserving the right to life on the chapter of AlAn'am (6): 151 and Chapter of Al-Isra (17): 31 and their right to obtain a good life among them on the chapter of At-Tahrim (66): 6 [1]. Father and mother are the first people who have the right to 
educate their children. They have their own way of educating based on their own type. Sometimes, they get the knowledge from their quran, own parents, environments, reading books and internet. Now, parents are not only as parents but they should be an educator. Yendra [2] stated that development of technology (Internet) could change someone's paradigm where it provides variety of information widely and unlimited. Hence, internet provides sources of education.

Related to the Quran and sunnah,, the guidance or instruction of educating is available in a general form. Therefore, there are differences in the pattern of education in each parent. There are those who educate their children with tenderness, others who educate with strong discipline and some even educate their children with a beating as a form of discipline. In its infancy and development, children are not always obedient to their parents' instructions, so there are parents who try to get their children discipline by beating their body like legs and hands [3]. Parents usually hit their children by relying on the hadith of the Prophet Muhammad SAW who told parents to beat their children when they were reluctant to establish prayers. In the hadith, it is expressed on pronunciation (murû auladâkum bi al-shalâti wa hum abnâ 'u sab'i sinîn wadhribûhum 'alaiha wahum abnâ ' $a^{\prime}$ asyri sinin) with the meaning of telling your children to pray when they are 7 (seven) years old and beat them when they are reluctant to pray at the age of 10 years old. In the Arabic dictionary, it is found that the word of dharaba has many meanings. There are some phrases of dharaba which have the connotation of beating as dharabahu bi'asha wa nahwihi with the meaning of beating, dharabahu 'alaihim al-zillah with the meaning of humiliating, dharaba' anhu safhan with the meaning of ignoring and dharabahu dharban mubarrihan with the meaning of hard beating. In connection to this hadith, the same pronunciation is also found in the Qur'anic chapter of AnNisa' (4): 34 about a husband who educates his wife by striking when his wife shows signs of ungodliness. Wadhribuhhunna pronunciation in this verse is explained in the traditions of the Prophet Muhammad SAW among them narrated by the Imam Muslim [4]. In this hadith, it is mentioned that the ability of beating wives is associated with the pronunciation of fadhribuhhunna dharban ghaira mubarrihin. The quran interpreter explains that the meaning of pronunciation fadhribûhunna is a painless educational beating that does not result in injury and break the bone because its purpose is to improve and not for other purposes. The pronunciation of fadhribûhum in children's education hadith is not explained the quality of the beating [5]. Therefore, the hadith scholars associate it with the ghair mubarrihin pronunciation as a beating that is not hard and does not hurt the children.

Educational researchers in various places react differently in addressing the hadith. There are among those who defend the hadith by giving various meanings that basically do not hit and some are criticized by mentioning if Islamic education tolerates violence. As one of the leaders of Islamic education, Abdullah Nashih Ulwan said that punishment could be given in the form of beating to children if it educates them. In this case, Setiawan said that the intention of that skill is appropriate rewards and punishments. Setiawan thinks this method is relevant to education today [6]. Maisaroh [7] said that violence against children occurs because parents do not understand their rights and obligations in educating children. This begins with their misconception in understanding the traditions that allow beatings against their children. Hadith seems to legitimize violence when violence should be avoided because violence in any form can harm others.

Nurdahlia [8] said that beatings to children is a conventional way (old) parents in educating their children. Beatings should be done as little as possible because there are many other better ways to educate. Imron argues about a new interpretation of the hadith that allows the father and mother to beat their children when they are reluctant to establish prayers. He said that the main spirit of the 
hadith is education that prefers wisdom and gentleness rather than violence as the practice of the Prophet Muhammad SAW in their education [9]. The Prophet never resorted to violence in educating his companions but it tends to be gently and it is proven to have a significant influence on their souls. Based on the variety of thoughts about dharaba pronunciation, it is known that education experts generally think positive if the beating is not the best way to educate even though the pronunciation is listed in the Qur'an and Sunnah.

Children are the group of people who cannot be held accountable in legal and religious obligations, because they become one of the syarak (al-'awâridh) barriers. It is based on the hadith narrated by Ali ibn Abi Talib that the Messenger of Allah said rufi'a al-qalam 'an tsalatsah:' an alnâim hattâ yastaiqiza, wa'an al-shaghîr hattâ yakbura, wa 'an al-majnun hattâ ya'qila au yufíqa with the meaning comes from the legal liability of three persons: from the moment he is sleeping until he wakes up, from a child until he is baligh (mature) and sensible (adult) and from the madman to his healthy mind. The referring child to the hadith is a child who has one age range until he reaches the age of maturity [10]. In the context of the responsibility of a child, the scholar divides the age category of the children to be responsible for his legal deeds into three parts. First, in'idâm al-idrâk which begins from birth to 7 years old. This age is called al-shabiyy and not mumayyiz even though a child has seen signs of tamyîz before the age of 7 years. If a child of this age commits a crime (jarimah) either hudûd or otherwise, then the child is not punished by the punishment of hadd, qisâsh and takzir but he is still penalized his property if the jarîmah concerns to the business of property such as compensation for damaging property belongs to someone else. Second, al-idrâk al-dha'îf which begins at age 7 to age of baligh (mature) around the age of 15 years.

At this age, a child is considered into mature legally but he is not yet mature indeed. Basically, no responsibility is required of children committing crimes at this age but they can be punished with educational punishment for crimes such as stealing, fornication, killing and injuring others. They are not punished by the principal punishment but they are punished by punishment of takzir as ta 'dîb (education) with the form of blemishing or beating punishment [11]. Third, al-idrâk al-tâmm begins at the age of 15 years. There are scholars who count it from the age of 18 years. Everyone at this age is punished with the ultimate punishment when they commit a criminal offense such as the punishment of qisâsh if they kill intentionally, the punishment of whipping if they commit adultery and other punishment.

In terms of laws and regulations, article 1, paragraph 1 of Law No. 23 of 2002 on Child Protection states that a child is a person who is not yet 18 (eighteen) years of age, including a child still in the womb. The age limit of children under this law is different from some other laws such as age under 16 years according to Article 7 paragraph 1 of Law No. 1 of 1974 on Marriage and 16/17 years under section 217 of Government Regulation No. 44 of 1993 on Vehicles and Drivers. When children within the age range set by the above law commit a criminal offense, they are punished differently from the penalties of adults [12]. In Article 45 to Article 47 of the Criminal Code, there are three legal options for a child (an immature person under the age of 16) that is returned to the parent / guardian, submitted to the government without any penalty or imposing a penalty on the offending child. The judge may impose a penalty, then the maximum penalty for a child crime is reduced by one third. If a crime committed by a child is punishable by death penalty or life imprisonment, then the child is sentenced to a maximum of 15 (fifteen) years imprisonment. Based on the explanation it is understood that a child can become a perpetrator of criminal acts and the law provides a choice of punishment for them. On the other hand, site facts show that by 2017 more than 
2000 (two thousands) children are serving criminal penalties in Juvenile Detention Center in all of Indonesia.

\section{METHODOLOGY}

In this research, research method used is description method. This method is a method of reading carefully, understanding each content with the overall reading technique, listening to each reading and then recording it in the data corpus. This is in accordance with opinion that these methods and techniques use the method of reading by understanding each of the contents of the whole and recording matters relating to this research [13]. Maryelliwati [14] mentioned that this method is said to be a method of description because the results of his research later in the form of a description of a state, event, and interpret the object in accordance with what it is.

\section{RESULTS AND DISCUSSION}

There are two terms commonly used by scholars at least in expressing a beating with the educational aim of at-ta 'dîb and at-ta'zîr. Ta' dîb as part of the way of educating based on the hadith of the Prophet Muhammad SAW addibû aulâdakum and followed by dharaba (beating) pronunciation as skill to beat. Therefore, the right or territory for ta'dîb by striking only in certain people is mandated by the Islamic law in the Qur'an and Sunnah namely the father to the children, the husband to the wife where the dharaba pronunciation is also found in the Chapter of An-Nisa 'verse 34, and a teacher to his students on the basis of ulama's thought/ijtihad. Although these three parties are given the right to educate by beating but the right is limited by other provisions that prevent educators from exceeding their authority [15]. There are many the case of beatings found out both husbands to wife, father / mother to child and teacher to students who ended up in the police. In this case, Islamic law affirms the obligation to the right-holders to be responsible for exceeding the educational authority which resulted in injuring and even killing the people he educated. They are required to account for their deeds and to replace the physical and psychological damage of the people they educate because they are basically educated by beating them permissible on condition of safety and goodness and not to injure or to destroy. A father in particular, he has rights to his children and punishes him by beating if necessary in order to educate and teach him noble character and to prevent him from doing bad things later on.

Besides the word ta dîb with the meaning of education, also known other terms in the region that is meaningful called takzir. Wahbah al-Zuhailiy [16] explains that originally takzir, according to language, means to prevent (al-man'u). Other definition is the help (an-nashrah), then the definition of takzir is widely known as the meaning of education (at-ta dîb). Definition of takzir, according to the term, is a punishment prescribed/action on the act of sin or jinayah which is not in the punishment of hadd and kaffarah. Based on the understanding it is known that the takzir finger is all the actions of $\sin / \sin$ that is not punishable by the punishment of hadd and kaffarah. Therefore among the punishment forms in the jarimah takzir is imprisonment, whips that do not exceed the hadd penalty, warnings either written or unwritten and so forth. The permitting of imprisonment in this jarimah takzir according to Ulama Hanafiyah is based on the Chapter of Al-Maidah (5): 33 on the pronunciation of aw yunfau min al-ardh. 
In addition, majority of other scholars are also based on the hadith of the Prophet Muhammad SAW narrated by Bahz ibn Hakim that indeed the Prophet Muhammad SAW had arrested a man for one indictment, then the Prophet freed him. This hadith is made into theorem by the scholars to do the punishment of imprisonment for the offender besides hadd and kaffarat. For example, it is permissible to hold a debtor who is reluctant to pay his debts. This takzir punishment is determined by the judge in accordance with the quality of the perpetrators' misdeeds. If the quality of his immorality can damage the public interest on a large scale, then the judge may impose the death penalty to the perpetrator [17]. Therefore, punishment in the jarimah takzir starts from the lowest form such as giving a warning to the highest punishment like death. From this description, we can conclude that the coverage of takzir is very wide compared to the coverage of the jarimah hudud. So, there is a great possibility to develop this jarimah on various state regulations to maintain the common good.

Based on the explanation above, it is understood that basically ta dib is the kind of educational punishment that a father or mother to the children, a husband to his wife and a teacher to his/her students when the people in their education do something that causes the third the party exercises its right to beat. The takzir is a type of punishment that the government has the right to be entrusted to the people under its leadership when they commit a crime. In this case, the punishment is aimed at one of them in order to educate them. If a person committing a criminal offense meets the adult age requirement, the government has no difficulty in punishing him in accordance with the applicable rules. It's just that when criminals are committed by children who have not reached adulthood (18 years), then the government faces a severe dilemma because children, especially in the age range 15-18 years old, have been able to commit the same criminal act, even more than the ability of adults. On the other hand, the hadith of the Prophet SAW allows parents to beat them when they are reluctant to pray at the age of 10 . Therefore, there is the possibility of the government giving a corporal punishment to those who are more than 10 years old when they commit a criminal or jarîmah.

Jarîmah in the concept of jurisprudence is known as the criminal act in Indonesian. Jarimah is defined by scholars as the prohibitions of syarak (shari'a) threatened by Allah SWT with the punishment of hadd and takzir. The prohibitions are criminal acts that are punishable by the punishment of hadd and takzir. The acts threatened through hadd punishment are very limited and involve a serious crime, since the meaning of hadd itself is the punishments that have been determined by its measure and limitations by Allah and His Messenger, that is the punishment of hadd for adulterers; people who accuse others of adultery, thieves, robbers, rebels to the legitimate government; people who consume alcohol; people who come out of Islam; people who kill other people, and people who persecute others. In contrast to the criminal act of hudûd, the punishment of takzir is a punishment for immoral acts which is not determined by the Shari'ah but is generally established by the state in the legislation. Basically, the meaning of takzir is at-ta 'dîb or educational punishment because it contains various punishments ranging from the lowest penalty such as warning to those committing minor offenses, whipping, defamation to the highest punishment such as death penalty [18]. Usually, the highest sentence of education is given to a person who commits an offense of takzir with the level of massive danger and damage. The goal is to educate people not to do the same thing.

Hadd and takzir punishments for the criminal acts above are provided by Allah SWT for those who can be held accountable for their actions. Usually, these penalties are given to the persons who 
are eligible for punishment. Common requirements include baligh and rational (adult). In the case of adult conditions, the children as immature persons are exempt from the provision to obtain the principal punishment when they commit the hudûd criminal offense as mentioned above. Nevertheless, a child who commits a hudd criminal act can not be spared from legal liability because they can still be held accountable from the point of takzir or ta' dib.

Generally, educational experts say that a child cannot be called a criminal because the acts committed by the child is not criminal. Similarly, the views on Islamic experts. The term that is widely given to children who violate the law is called juvenile delinquency. It's just that the involvement of children/ adolescents in criminal acts is inevitable because field facts show an increasing trend of criminal offenders among children and adolescents. Data from the Ministry of Youth and Sports in 2009 noted that juvenile delinquency was included in the Important Event of Security disorder and Society Order (PPGK). A total of 3280 children/ adolescents engaged in crime increasing $4.3 \%$ from the previous year. In 2014, there have been 3.8 to 4.1 million narcotics abuse cases and child and adolescent offenders including into one category. Data from all provinces in Indonesia recorded 773 male and 19 female prisoners and 2051 male and 43 female prisoners. Most child prisoners are in East Java as many as 134 children and most prisoners are in South Sumatra as many as 214 children. When viewed from the quality of crimes committed, there is no fundamental difference between children/ adolescents with adults. Children / teenagers have been able to commit criminal acts just like adults do. Alifah [19] expressed the variety of crime committed by children in Kutoarjo. For example; She noted there were 42 children as prisoner who were found guilty of sexual misconduct, 7 children as the theft and 5 children were found guilty of premeditated murder. When the killings were committed, they were still under 16 . These data also show that most sexual crimes are committed by children. The same thing also revealed by Rokamah [20]based on UPPA data of Resort Police and Committee of Protection of Woman and Children (KPPA) noted more than $80 \%$ of victims of sexual violence are children and perpetrator of sexual violence also dominated by them in age category of children. The data and facts above show that educators and law enforcement cannot turn a blind eye to the reality of children as perpetrators of crime even though they cannot be called a criminal.

In general, intellectuals in education do not approve of violence (beating) as an educational reason. They, in accordance with their respective fields, are trying to find the right solution to address the increasing of bad behavior in children. The guidance of child criminals in a special prison for children does not seem to produce maximum results and the detained children are increasing every day, so that child prisons in each province have exceeded the capacity of the shelter (over capacity). This means that the Child Correctional Institution/prison is no longer a conducive place to nurture and educate them. The child and all his conditions are always part of the education talks and the laws relating to them. Proper education is the right they have to secure to ensure their future survival. On the other hand, the acquisition of these rights cannot be separated from the laws surrounding them. In the discussion of the crime (jarîmah) in Islamic law, the child and his condition are always put forward in formulating the conditions permitted to him to be given the maximum punishment. There are at least three elements to call an act as a crime (jarimah), namely: first, the formal element (rukn al-syar'iy) that is the rule that the act is forbidden and the offender is threatened with a certain punishment. Secondly, the material element (rukn al-maddiy) is the existence of a criminal act committed by a person. Third, the moral element (rukn al-adabiy) is the state of a criminal offender who can be held accountable for his law. Not all criminals can be held accountable 
for their actions because there are certain things that prevent them themselves. For example, the perpetrator is forced to commit a criminal, the perpetrator in a state of crazy or still in the age of the children. When a child commits a criminal act, the jarîmah or criminal element cannot be relied upon to him, so that this situation becomes a barrier to the imposition of a fundamental punishment to him. That does not mean the children are free from punishment because the state has the right to give takzir punishment to him as an educational effort.

In the concept of jurisprudence, jarîmah consists of at least three types called hudûd, qisâsh/ diyat and takzir. Hudûd and takzir contain the threat of punishment to the soul and physical offender. Jarîmah hudûd consists of adultery with the whipping; the accusation of adultery with the punishment of whipping; the theft with the punishment of the hand-cutting; the robbery with the death penalty, the cross, the cutting of the hands and legs, the prison, consuming the drunken drinks with the punishment of the whipping; the rebellion with the principal punishment is killed/fight and come out of Islam with the principal punishment is killed. Qisâsh/diyat is a punishment for people who commit murder and persecution. Both types of jarîmah both hudûd and qisâsh-diyat require corporal punishment even the soul of the perpetrator. These penalties shall be executed upon the fulfillment of the terms of sentencing. Among these conditions relates to the problem of baligh age and intelligence. If the perpetrator has been baligh and intelligent, then he fulfills the requirement to be able to account for his actions before the law. Problems arise when jarîmah hudûd, qisâshdiyat is done by people who have not baligh and children, especially children who have intelligent and been able to distinguish between something bad and good (mumayyiz).

Based on several types of jarîmah above, it can be put forward an example of criminal acts committed by children of adultery and rape (sexual crimes). The main or principal punishment for the adulterers among them is the whacked / hit at the back as stated in the Chapter of An-Nur (24): 2. If a child commits adultery, the cleric assesses his status as a boy or girl and within his age range. If a boy commits adultery with a daughter, then the death penalty for both is based on a hadith narrated by Ali ibn Abi Talib above. When the adultery inflicts the girl's virginity, the boy is obliged to pay the girl's dowry and the judge may impose the punishment of takzir and ta'dîb on both. The punishment of takzir for boys in the form of beating and in girls is not in the form of beating in education. Other scholars assess the status of children who commit adultery from the side of children's intelligence before entering the age of baligh. Usually, it occurs in children aged 10 to 18 years old. If a boy at this age commits adultery with a woman, then the scholars differ on the punishment that should be given to him. Generally experts say that children aged 15-18 years old of adultery can be sentenced to hadd al-zina at him that is hit or beaten at the back. They judge that this hadd has been appropriate for them even if they are immature based on dream of intercourse for the first time as a sign of baligh. On the other hand, this age limit is required as a measure because of the different baligh size in each child. A boy becomes baligh when he had already had a wet dream (ihtilâm) and girls become baligh when experiencing the first menstruation, dreams of intercourse or pregnancy. It's just that these baligh signs sometimes appear earlier and sometimes appear later depending on the condition of each child. Therefore, scholars tend to use the age benchmark as a sign of a boy's baligh to punish by beating them in the name of education. However, usually the signs of baligh in a child appear within this age range [21].

On the one hand, it can be understood the thought of the experts of Islamic education about avoiding punishment in students with a beating way. This happens because the amount of pressure both from the experts of Islamic education and non-Muslims on the application of punishment is 
considered a violation of human rights, especially the rights of children. On the other hand, it is said that punishment in the form of beating may not succeed in achieving the desired educational goals. This kind of thinking is also impressed in chapters 66 and 67 of Qanun Aceh Number 6 in 2014 About Jinayat Law. These two chapters are like symbolizing the whipping over the age of 12 years old. Article 66 states that juvenile offenders who are not yet 18 years of age will be examined in accordance with child criminal justice. However, in article 67 it is mentioned that if a child over the age of 12 years old and under 18 years old of age performs one jarîmah, then the child may be subjected to 'uqubat at most one-third (1/3) of' uqubat specified for an adult. Based on these two articles, it can be taken partly understanding if this Qanun Aceh will punish the child of the perpetrator as much as $1 / 3$ of adult punishment. If a child commits adultery, then in accordance with article 33, paragraph 1, the punishment is whipped 100 (one hundred) times. This is understood from the word 'uqubat which exists only in Qanun but it is not in the child's juvenile justice law. On the other hand, this article becomes the basis for building courage of judges in determining the physical punishment of a criminal offender who deserves to be properly punished.

\section{CONCLUSION}

Hadith of the Prophet Muhammad SAW gave the father the right to beat his children as part of the education process. The Shari'ah of Islam imposes limitations on the quality of the beating on the lawless wife (nusyûz) to her husband. The allowance of the husband beating to the wife described in the Qur'an of Chapter An-Nisa '(4): 34 which is limited by the hadith pronunciation of the quality of the ghair mubarrihin beating. The same limitation is not found in the hadith's pronunciation of educating children who are reluctant to establish prayers by beating. The allowance of a father or mother to beat the children who are reluctant to establish prayers extends to other areas such as the permitting of the state to punish the child as a jarîmah performer who desires corporal punishment and the soul of the perpetrator. That is, the age limit of 10 years old into the criteria of Ulama in determining physical punishment to children who committed a crime or jarîmah with educational reasons.

One important thing that can be understood that Allah SWT and Rasul did not issue the dharaba pronunciation in al-Qur'an and Sunnah with the aim to persecute his people but to gain goodness and benefit. Implementation of punishment is basically aimed at educating both the child as the perpetrator and the parents and the community in the environment. Therefore, the spell beating (dharaba) as an educational punishment has a specific purpose. However, the recitation of the hadith cannot be ignored simply because Allah SWT and Prophet Muhammad SAW know the purpose of the suggested method. Nothing is futile in any material set out by Allah and His Messenger as proposed in the Cahpter of Ali Imran (3): 191. Considering the development of children today, it can be seen that educating certain children of criminals by beating has gap to be implemented. It seems to be more effective to do than to be imprisoned in an increasingly congregated juvenile and increasingly a the state burden.

\section{ACKNOWLEDGMENTS}

The editors of this special issue extend their sincere thanks to the contributors and reviewers who made this issue possible. We deeply appreciate Carolyn Watson's administrative support and David 
Butz's editorial guidance. This issue is the fruit of the exceedingly productive discussions that took place at the 2016 Global Movement Assemblages symposium. We extend our sincere thanks to all the participants. We acknowledge the dedicated work by Kushan Azadah, Karolina Walczyk, and Md Firoz Alam in documenting the symposium and producing the videos. We especially appreciate the leadership by Margot Francis in conceiving and organizing the symposium and the logistical support and financial administration provided by Maria Callaghan. Finally, we acknowledge with gratitude the financial support provided by Brock University's Social Justice Research Institute and the Canada Research Chair in Social Justice in making this project possible.

\section{REFERENCES}

[1] Al-Jassâs, Ahkâm al-Qur 'ân, Jilid II. Beirût: Dâr al-Kitâb al-'Arabiy, 1986.

[2] Y. Yendra and W. Rahmat, "Introduction Blended Learning Designs on Introduction to Linguistics at West Indonesian,” Int. J. Eng. Technol., vol. 7, pp. 310-313, 2018.

[3] M. ibn I. Al-Kahlaniy, Subul al-Salâm, Jilid III. Beirût: Dâr al-Fikr, 2000.

[4] I. Muslim, Sahih Muslim, Jilid II,. Beirût: Dâr al-Fikr, 2005.

[5] A. Imron, "Re-interpretasi Hadis Tarbawi tentang Kebolehan Memukul Anak Didik," J. Pendidik. Islam, vol. 1, no. 2, pp. 141-157, 2012.

[6] A. Setiawan and E. Kurniawanto, "Metode Pendidikan Islam Masa Kini dalam Keluarga Perspektif Abdullah Nashih Ulwan," Educ. J. Pendidikan, Pengajaran, dan Pembelajaran, 2016.

[7] M. Maisaroh, "Kekerasan Orang Tua Dalam Mendidik Anak Perspektif Hukum Pidana Islam," RIGHT J. Agama dan Hak Azazi Mns., vol. 2, no. 2, 2017.

[8] D. U. Nurdahlia and E. Setyowati, "Pemberian Hukuman 'Pukulan' dan Pembiasaan Berbahasa dalam Pendidikan Islam sebagai Solusi bagi Orang Tua," J. Pendidik. Islam Indones., vol. 1, no. 2, pp. 225-236, 2017.

[9] Al-Mâwardiy, al-Ahkâm al-Sulthâniyah. Mesir: Maktabah wa Mathba'ah Musthafa al-Bâb al-Halabiy, 1966.

[10] A. al-Q. 'Audah, Al-Tasyrî’' Al-Jinâîy Al-Islâmiy. Kairo: Maktabah Dâr al-'Urûbah, 1997.

[11] A. Dâud, Sunan Abi Dâud, Jilid I. Beirût: Dâr al-Fikr, 2003.

[12] H. Alrasid, Himpunan Peraturan Perundang-undangan Republik Indonesia Menurut Sistem Engelbrecht. Jakarta: Ichtiar Baru Van Hoeve, 2006.

[13] M. Wahyudi Rahmat, "Sinisme Dalam Kaba Sabai Nan Aluih Suatu Bentuk Pentingnya Bahasa Bahasa Ibu: Kajian Pragmatik," Curricula J. Teach. Learn., vol. 2, no. 1, 2017.

[14] M. Maryelliwati, W. Rahmat, and E. Kemal, "A Reality of Minangkabau Language and Literature and its Transformation to a Creation of Performance Works," J. Gramatika J. Penelit. Pendidik. Bhs. dan Sastra Indones., vol. 4, no. 1, pp. 62-70, 2018.

[15] A. Syarifuddin, Ushul Fiqh I. Jakarta: Kencana Publisher, 2008.

[16] W. Al-Zuhailiy, al-Fiqh al-Islâmiy wa Adillatuhu, Jilid VII. Beirût: Dâr al-Fikr, 1997.

[17] W. Fitriani and D. Hastuti, "Pengaruh Kelekatan Remaja dengan Ibu, Ayah, dan Teman sebaya terhadap Kenakalan Remaja di Lembaga Pembinaan Khusus Anak (LPKA) Kelas II Bandung," J. ilmu Kel. Konsum., vol. 9, no. 3, pp. 206-217, 2016.

[18] I. al-Qurthubiy, al-Jâmi' li Ahkâm al-Qur 'ân, Jilid III. Beirût: Dâr al-Fikr, 2003.

[19] A. M. Alifah, N. Prihartanti, and I. Rosyidi, "Dinamuka Psikologis Narapidana Anak Pelaku 
Pembunuhan: Studi Kasus di Lapas Anak Kutoarjo," Indig. J. Ilm. Psikol., vol. 13, no. 2, 2016.

[20] R. Rokamah, "Restorative Justice bagi Anak Pelaku Tindak Pidana Perkosaan Anak Perspektif Hukum Islam dan Hukum Positif," Justicia Islam., vol. 10, no. 2, 2013.

[21] K. Saddhono, N. E. Wardani, and C. Ulya. "Sociopragmatic approach on discourse structure of friday prayer's sermon in java and madura island." J. of Lang and Lit, vol. 6 no. 1 pp 2629,2015 